\title{
Flooding in river mouths: human caused or natural events? Five centuries of flooding events in the SW Netherlands, 1500-2000
}

\author{
A. M. J. de Kraker \\ VU-University, CLUE (Research Institute for the Heritage and History of the Cultural Landscape and Urban Environment), \\ De Boelelaan $1081 \mathrm{HV}$, Amsterdam, the Netherlands
}

Correspondence to: A. M. J. de Kraker (a.m.j.de.kraker@vu.nl)

Received: 4 December 2014 - Published in Hydrol. Earth Syst. Sci. Discuss.: 30 January 2015

Revised: 21 April 2015 - Accepted: 29 April 2015 - Published: 9 June 2015

\begin{abstract}
This paper looks into flood events of the past 500 years in the SW Netherlands, addressing the issue of what kind of flooding events have occurred and which ones have mainly natural causes and which ones are predominantly human induced. The flood events are classified into two major categories: (a) flood events that were caused during storm surges and (b) flood events which happened during warfare. From both categories a selection of flood events has been made. Each flood event is discussed in terms of time, location, extent of the flooded area and specific conditions. Among these conditions, specific weather circumstances and how long they lasted, the highest water levels reached and dike maintenance are discussed as far as flood events caused during storm surges are concerned. Flood events during warfare as both offensive and defensive strategies are relevant; the paper demonstrates that although the strategic flood events obviously were man-made, the natural feature, being the use of fresh water or sea water, of these events also played a major role. Flood events caused during storm surge may have an obvious natural cause, but the extent of the flooding and damage it caused was largely determined by man.
\end{abstract}

\section{Introduction}

In this paper five centuries of flooding events in the SW Netherlands are analysed. This former delta area is dominated by the mouths of the rivers Meuse, Eastern and Western Scheldt (van de Spek, 1997). It is comprised of the Dutch province of Zeeland, the western section of North Brabant and the region south of Rotterdam (Fig. 1). The area was an archipelago consisting of islands on which many small polders were interwoven with dikes into one big patchwork of defences. As the area borders the southern North Sea, tidal water is funnelled into the delta daily, some of which could reach dangerously high levels during winter time. Since medieval times the area has been exploited, providing people with their livelihood, such as farming, peat cutting and fishing. At points in time the area was also a theatre of war during which a strategy of flooding was applied, which also adversely affected the landscape. Therefore the main research question of this paper is to investigate how many of the flooding events have natural causes and how many are a result of anthropogenic interference. As the list of flooding events in the area is too long, the focus will be on the major 16th century flooding events, in particular three cases from the 17th and 18th century, and the two major flooding events of the mid-20th century.

\section{Background}

Since AD 1000 local communities - at that time still living on low dwelling mounds - began to build low dikes in the archipelago of the mouths of the rivers Meuse, Eastern and Western Scheldt. Gradually small islands were extended and some were joined into even bigger ones by dikes and dams. Many centuries later islands such as Schouwen and Duiveland, but also Goeree and Overflakkee, became bigger islands. On every island settlements were founded and on the major islands towns rose.

This coastal area was attractive for settlement because of its natural resources. The clay soil was very fertile and suitable for arable farming and, where areas remained under the 


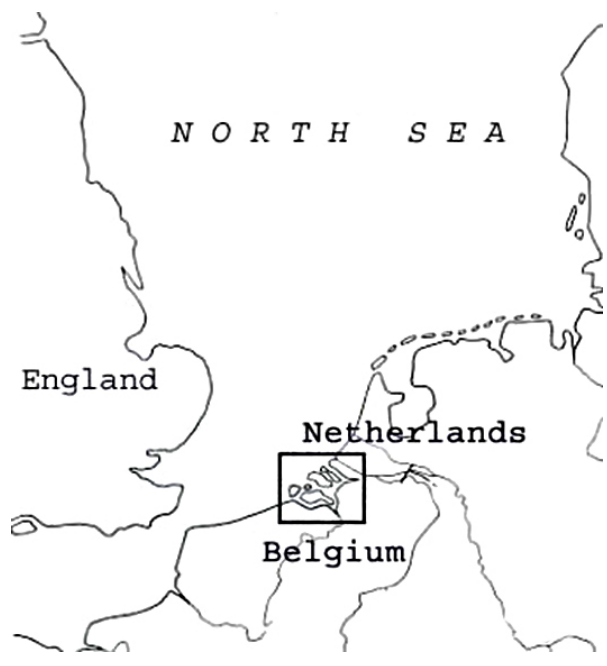

Figure 1. The former archipelago of the mouths of River Western Scheldt, Eastern Scheldt and River Meuse. The study area in the box consists of the Dutch provinces of Zeeland, the western part of North Brabant and the area south of Rotterdam.

influence of the tides, there was sheep farming (Verhulst, 1995, 64-76). As the process of land reclamation developed, local communities were joined by big investors such as feudal lords, monasteries and hospitals located in towns such as Ghent and Bruges. As the medieval period ended, land reclamation and dike building were predominantly undertaken by big investors (de Kraker, 2011a, b). Their main task was to maintain the dikes in order to keep out the outside water and to maintain a network of ditches with a sluice in order to discharge the polders of fresh water on the inside. Long-term water discharge of polders meant a gradual drop in surface level, because of the thick layer of peat in the subsoil that compacted at several locations.

Next to farming, these thick peat layers were also a second major natural resource of the archipelago. Large peatbogs had formed since $5000 \mathrm{BC}$ in a fresh water environment protected from the North Sea by a system of coastal barriers on one hand, while on the other hand the groundwater table slowly rose corresponding to a slowly rising sea level. The flow of water through the rivers Scheldt and Meuse contributed to the expansion of the peatbog area (Baeteman, 2013; Weerts, 2013). After the 3rd century AD peat growth was interrupted by large-scale flooding. This affected the peat in two ways. At some places it was removed by clay deposits; in most places, however, peat was penetrated by sea water and covered by a fresh clay layer. Peat could therefore be used for two purposes: fuel and salt extraction (de Kraker et al., 2008). At the end of the medieval period some twenty towns were active in making salt from peat, employing thousands of workers (de Kraker, 2007). It meant that in vast areas peat was cut and therefore the original surface level of the old polders dropped (Borger, 1992; van Dam, 2001). In spite of regulations forbidding entrepreneurs to cut peat in polders too close to dikes, the process of land subsidence continued unabated. The alternative was to cut peat at low tide in the saltmarsh or flooded areas.

On the one hand, the sea had contributed much to building the landscape of the archipelago in terms of clay soils and salt in the peat layers; on the other hand, it also had its downside. Contemporaries building dikes could determine how high and how broad its base had to be, but storm events towards gale force (8-9 Beaufort) or even storm force (1011 Beaufort) could not be foreseen. As the wind turned to the northwesterly direction and coincided with New Moon or Full Moon, water levels could be pushed up to a level of more than $0.5 \mathrm{~m}$ above the highest dike levels, causing flooding with dikes levels varying from 3.85 to $4.95 \mathrm{~m}$ (Van de Ven, 1993; De Kraker, 2005). As the water of the North Sea was not only funnelled into the southern North Sea but further upstream into the mouths of the rivers Meuse, Eastern and Western and Scheldt, polders lying at the far end needed to have higher dikes than those located at the river mouths.

It was not until the mid-19th century that it became possible to foresee how the weather would turn and what the levels of daily high water levels, in particular spring tide levels, would be. From that period onwards hydraulic engineers regularly monitored and measured top levels of all the dikes in the area and made plans to improve them. Making plans is one thing, but implementing them on all the so-called free polders, which were completely autonomous, was another. Generally the administration of such polders chose to govern their polder and maintain their dikes at the cheapest price, rather than spending "spoilt" money on raising top levels of dikes mainly aimed at pleasing the tax paying landowners. This radically changed after the major flooding of 1953 .

\section{Materials and methods}

This paper builds on ongoing multi-disciplinary research into how the landscape of the study area has changed during the past five centuries. This consists of extensive research of documentary evidence which can be subdivided into the following categories. Documents relate to land ownership and land use, such as manorial accounts of which monasteries and nobility are most important. Accounts of the maintenance of sea defence such as dikes, dunes and sluices which were controlled by the many water boards in the area. If preserved, each single polder had to keep an annual account of dike maintenance. Correspondence of various stakeholders in flooded areas and local administrations and provincial governments are of interest, as well as historical maps made after flooding events. All of this documentary evidence provides information on flooding events and specific details about how, where and when flooding happened, what was the extent of the damage and how this could be repaired. For some flooding events (1715 and more recent ones), specific damage assessment reports were made. In conjunction with 
Table 1. Flooding caused by storm surges in Zeeuws-Vlaanderen and elsewhere in Zeeland, 1014-1953.

\begin{tabular}{llllll}
\hline Year & Old style & New style & Year & Old style & New style \\
\hline 1014 & 28 September & 2 October & 1488 & 25 December & 3 January 1489 \\
1042 & 2 November & 6 November & 1491 & 14 September & 23 September \\
1134 & 2 October & 7 October & 1493 & No exact date & \\
1248 & 28 December & 3 January 1249 & 1497 & No exact date & \\
1262 & 28 January & 3 February & 1502 & 16 October & 26 October \\
1268 & 28 January & 3 February & 1509 & 26 September & 5 October \\
1288 & 14-17 December & 20-23 December & 1511 & 14 December & 24 December \\
1330 & 24 December & 31 December & 1516 & 26 December & 5 January 1517 \\
1334 & 23 November & 30 November & 1530 & 5 November & 15 November \\
1341 & No exact date & & 1532 & 2 November & 12 November \\
1357 & 24 December & 31 December & 1552 & 13 January & 23 January \\
1374 & 9 October & 16 October & 1552 & 15 February & 25 February \\
1375 & 8-10 October & 16-18 October & 1570 & 2 November & 12 November \\
1394 & 21 January & 29 January & 1606 & & 27 March \\
1398 & No exact date & & 1609 & & 18 February \\
1404 & 19 November & 28 November & 1671 & & 22 September \\
1409 & 10 February & 19 February & 1682 & & 26 September \\
1421 & 19 November & 28 November & 1683 & & 18 February \\
1424 & 19 November & 28 November & 1695 & & January \\
1436 & 31 October-1 November & 9-10 November & 1715 & & 2 March \\
1446 & 10 April & 19 April & 1717 & & 25 December \\
1449 & 22 March & 31 March & 1808 & & 14-15 January \\
1468 & 21 October & 30 October & 1809 & & 2 March \\
1472 & 5 October & 14 October & 1906 & & January \\
1477 & 27 September & 6 October & 1953 & & \\
\hline & & & & & \\
\hline
\end{tabular}

historical geographical research, archaeological information of specific locations is also used, features and even settlements which disappeared shortly after a flooding event and were buried under new clay deposits. In this respect aerial survey proved to be a very useful tool, where the focus was on crop marks. Finally, geological maps $(1: 50000)$ were used along with the digital elevation model of the Netherlands (Actueel Hoogtebestand Nederland). In particular, old soil maps with cross sections of subsoil layers of Holocene peat proved to be very useful in clearly identifying locations where new tidal channels had removed peat or had not affected the old layer at all.

The general literature about flooding events in the Netherlands mainly focusses on the 1953 event and its aftermath as far as the SW Netherlands is concerned and the 1916 event as far as the Dutch provinces of Holland, Utrecht, Gelderland and Overijssel, surrounding the former Zuiderzee, are concerned. The 1953 event became the onset of the many delta works carried out here and the 1916 event became the onset of the closure of the former Zuiderzee and large-scale land reclamation in the area. Most of the studies focussed on hydraulic engineering aspects (van de Ven, 1993), and some on the human suffering and the initial causes of the event (Slager, 2003). The 1953 flooding was also the start of a broad scientific research programme of historic flooding events caused by storm surges and river flooding 7th cen- tury AD 1700 (Gottschalk, 1971, 1975 and 1977). Many case studies of the history of small polder areas published by small water boards located in the coastal areas of Holland and Zeeland also provide detailed information on single flooding events (Kool-Blokland, 2003; de Kraker and Bauwens, 2000; van Tielhof and van Dam, 2006). Recently there has also been a focus on flooding within the framework of climate change (all extreme weather events) both in coastal and river areas and the perception of flooding events by contemporaries from the past (Bosch, 2010; van Dam, 2012; de Kraker, 2013).

\section{Flood events, 1500-2000}

\subsection{General}

The major flooding events in the research area referred to as storm surges are well known. Gottschalk (1971, 1975, 1977) has studied these events by using chronicles and related documents which enabled her to make a distinction between actual and erroneous events (Table 1, Fig. 7). If we include the occasions on which parts of the area flooded at other points in time than during storm surges (anthropogenic caused floods - Table 2, Fig. 8), the picture becomes more complete, except for those polders that flooded because their dikes collapsed, at places where the meander of a river moved closer to the 
Table 2. Flooding caused during warfare in Zeeuws-Vlaanderen and elsewhere in Zeeland, 1491-1944.

\begin{tabular}{llll}
\hline Year & Old style & $\begin{array}{l}\text { Size of flooded } \\
\text { area }\end{array}$ & Location \\
\hline $1491 / 1492$ & No exact data & $>100$ ha & Bruges area \\
1584 & February-July & $\begin{array}{l} \pm 5000 \text { ha } \\
\pm 7500 \text { ha }\end{array}$ & $\begin{array}{l}\text { Zeeuws-Vlaanderen } \\
\text { Zeeuws-Vlaanderen }\end{array}$ \\
1586 & July & $\begin{array}{l}\text { Zeeuws-Vlaanderen } \\
\pm 3500 \text { ha }\end{array}$ & Zeeuws-Vlaanderen \\
1621 & \pm 5500 ha & 775 ha & Zeeuws-Vlaanderen \\
$1702 / 1713$ & & 2200 ha & Zeeuws-Vlaanderen \\
$1747 / 1749$ & & 1330 ha & Zeeuws-Vlaanderen \\
$1784 / 1785$ & & 950 ha & Zeeuws-Vlaanderen \\
$1794 / 1795$ & & 5800 ha & Zeeuws-Vlaanderen \\
$1942 / 1944$ & & 29000 ha & Island of Schouwen-Duiveland and \\
1944 & April & & the islands of Tholen, St. Philipsland \\
& & $70 \%$ & Island of Walcheren \\
\hline
\end{tabular}

foot of the dike. Such incidents could happen during very low tide in any given season caused by the strong ebb and flow of the water undermining the sandy layers underneath clay and peat; of such flooding events no inventory has yet been made.

\subsection{Flood events 1509-1511}

On 26 September 1509 (n.s. 6 October) a major storm surge hit the archipelago and many polders flooded. A chronicler at Antwerp wrote:

On Saint Cosmas and Damian's night there was a big flood and tempest of wind causing many dikes to collapse and consequently flood. We also saw wagons floating over the Scheldt ferry outside the Croonenborch gate ... There came word about the big flood from Holland and Zeeland from which it appeared that not all the land was flooded, but only some, such as Cats, Stavenisse, Hontenisse and in many more waters were already disappearing ... (Royal Library).

In the Zwin area of Bruges, town authorities spoke of the event in terms of bad weather and high flood (Town Archive). Although this event is counted among the big disasters of the 16th century (Essink, 2013), perhaps less than $10 \%$ of the areas actually flooded, which comes fairly close to the assessment of the Bruges officials. As repairs were rapidly undertaken, most of the flooded land was in use again by 1510. In some places, however, landowners were unwilling to cooperate in undertaking the repairs. Such areas were even more vulnerable when a second storm surge hit the area on 14 December 1511 (n.s. 24 December) (National Archives of Belgium and others). Apart from the extreme weather event, most of the flooding could be attributed to the fact that either dikes breached in 1509 were still freshly made and therefore too brittle to withstand the big waves, or some areas were left

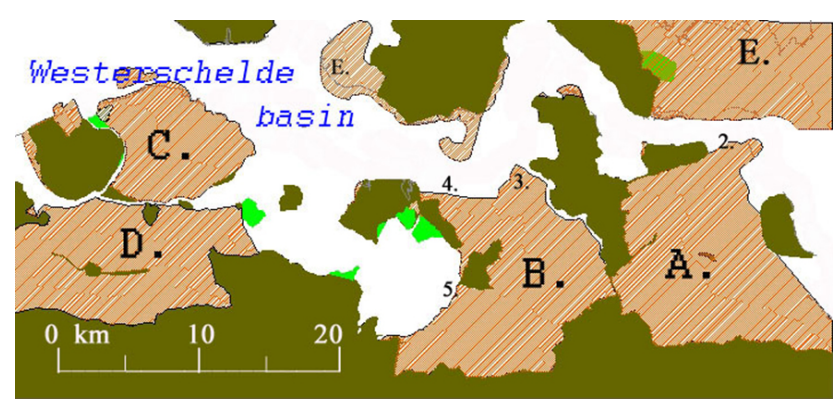

Figure 2. Strategic flooding during the Eighty Year's War (15681648 ) in Zeeuws-Vlaanderen. (A) Flooded in February 1584 at no. 2., (B) area flooded in July 1584 and the southern area flooded in July 1586 at no. 5. (C) Area flooded in 1584. (D) Area flooded in 1584 , then reclaimed again and flooded again in 1621-1622. (E) Areas flooded during storm surges, 1530, 1532 and 1570.

flooded in 1509, which two years later made it easier for the high flood to penetrate deep into the older polders with both dikes and a surface level which was too low.

Areas in the province of Zeeland, north of the Westernscheldt basin, were very badly hit during storm surges of the 16th century, of which vast areas remained under water for a very long time (Fig. 2, areas E).

\subsection{Flood events of 1584-1586}

During the Eighty Year's War (1568-1648) the Spanish army campaigned in northern Flanders to recapture the towns of Bruges, Ghent and Antwerp, which held the rebel side. The rebels resisted the policy and reforms made by Philip II, King of Spain and hereditary ruler of the Low Countries. After the suppression of the rebel uprising in 1566, the opposition was led by William of Orange, based at Middelburg (Zeeland) across the Western Scheldt, who encouraged the besieged towns to stand firm against the Spanish. Meanwhile the Span- 
ish systematically subdued the countryside of all the polders in the areas, closing in on the three towns on one hand and gaining control over the Western Scheldt on the other hand. It made it even harder for the rebel war ships to send relief to besieged towns. They therefore decided to remove the Spanish from the countryside and to keep them away from controlling the Western Scheldt, which would make it easier for the rebel side to relieve the towns (Groenveld et al., 2008, 117-119).

This led to the adaptation of the strategy of deliberate and large-scale flooding of the polders on the Flemish side of the Western Scheldt. Experts were summoned to Middelburg to explain where the dikes and sluices could be best destroyed in order to guarantee the largest possible area to be flooded (Fig. 2). In order to relieve Antwerp, the seawalls were destroyed at Saeftinghe in February 1584 (now Verdronken Land van Saeftinghe, $51^{\circ} 21^{\prime} \mathrm{E}$ and $4^{\circ} 96^{\prime} \mathrm{N}$; see Fig. 2, no. 2, area A) (Zeeland Archives, Middleburg, Netherlands and others). At Campen the seawall was breached in May 1584 (now west of the present hamlet of Kampen, $51^{\circ} 21^{\prime} \mathrm{E}$ and $3^{\circ} 57^{\prime} \mathrm{N}$, Fig. 2, no. 3, area B), and east of Terneuzen the seawall was breached in the same month (now near the sluice of Othene in the town of Terneuzen, $51^{\circ} 19^{\prime} \mathrm{E}$ and $3^{\circ} 51^{\prime}$ N, Fig. 2, no. 4) and at Sluice-Aardenburg this also happened in the summer of 1584 (Zeeland Archives, Estates of Zeeland). In July 1586 another inundation was caused near Axel (Fig. 2, no. 5, area B), but this did not serve to relieve Ghent, which was already dominated by the Spanish (de Kraker, 1997, 335-337). The carefully chosen places to make breaches in the seawall or to simply take out a wooden sluice had a devastating impact on the landscape, but this strategy completely missed its directly anticipated goals. Bruges, Ghent and Antwerp were subdued by the Spanish in the course of 1584 and 1585, leaving the rebel side empty handed. The impact of these flooding events on the landscape was without precedent, because even secondary dikes (dikes in the second line) were also affected, finally flooding about $2 / 3$ of the late medieval landscape. The flooded zone also isolated the area from its historical hinterland, from which money usually came and decisions were made for repairs. From the rebel side all possible money for repairs went to the military and was not spent on newly conquered areas, of which control remained uncertain. As the area became a frontier between the two warring parties, there was no rush to undertake fast repairs. Besides, nobody could survive in the flooded area. In fact, the vast flooded land, which separated the warring parties, was gradually considered to be a rather practical solution to avoid any kind of hostile engagement in the field.

If there was no eagerness to reclaim the flooded land, what happened to it? The military took even further control of the flooded polders by building earthen fortresses at strategic points. These were built both by the Spanish and the rebels, leading to the development of a chain of fortresses or Spanish line of defence and a rebel chain of fortresses or Dutch line of defence. Over the next two centuries these defence lines, after 1648 taken over completely by the Dutch Republic, became the blueprint for further land reclamation.

Another major impact on the landscape as a result of these strategic inundations was the start of a new process of erosion and deposition. At places where dike breaches were caused, deep new channels were formed which slowly developed into new large creeks (the Otheense Kreek, Hellegat and Vlaamse Kreek). As the process of reclaiming these areas started very late, most of the minor creeks had already silted up again, yielding new rich clay soils for arable land. Silting up also occurred in areas which had been overexploited during the late medieval period, which had caused large-scale subsidence of surface level, leaving behind a new thick clay layer. At most places where the late medieval landscape had been overexploited, a thick new clay layer covered all remnants of buildings, roads and ditches. Also, medieval villages were abandoned and finally lost (Hontenisse, Aendijcke, Beoostenblije and Othene). Some of these villages have never been found; others are under the new deposits in recently reclaimed polders.

Closely related to the long duration of the strategic flooding events and the gradual reclamation of land afterwards is the deep impact on the population. As the original inhabitants had to abandon the flooded lands, gradually new inhabitants settled again, but this time mostly coming from the Dutch Republic, mainly being of Protestant belief and speaking with a slightly different tongue.

It needs to be said that, in the province of North Brabant, the area of Bergen op Zoom and its vicinity and some adjacent polders further to the northeast also experienced strategic flooding, of which the first happened in 1584 east of the town. Polders and villages disappeared. It was not until about 1700 that most areas were gradually recovered again, this time without villages (Kluiving et al., 2006).

\subsection{Flooding of 1682-1715 compared}

Another flooding event occurred on 26 January 1682, during which about half of the area of Dutch northern Flanders was submerged, while on the other islands of the archipelago and parts of North Brabant, the area flooded ranged from $10 \%$ up to $25 \%$ (Fig. 3). The following extended quote summarises what happened around Antwerp:

On the 26 January 1682 there was a big tempest with a high flood and according to the word that came from Antwerp this was never seen nor heard of before. Because of the extreme violence caused by this flood water flowing into polders of Kallo where about all of the polders drowned as far as the fort Vlaamsche Hooft located on the left bank of the river Schelt. Only those polders having strong dikes such as the Beverenpolder, Verrebroek and around were spared. It was a real deluge because everywhere there were dead bodies of people and 


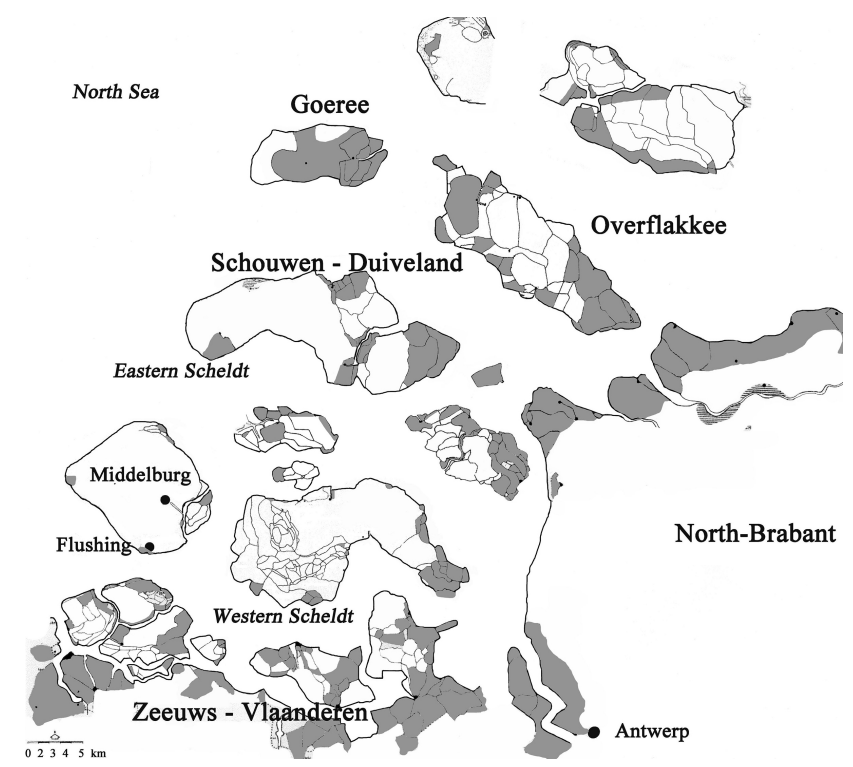

Figure 3. Reconstruction of the flooded areas (shaded) on the main islands and in the western part of North Brabant during the storm surge of 26 January 1682 (Gottschalk, 1971-1977).

dead animals floating and a lot of grain, household goods, stables and even entire barns in such large numbers that it was hard to describe it all. Damage was estimated to run in the millions and thousands of people were ruined (Municipal Library).

Officials inspecting the broken dikes and going into the flooded lands saw and heard numerous people who had taken refuge on the rooftops of their houses, barns and stables. They could only get down safely if they were rounded up by rowing boats and barges. But most of them were too frightened because they feared the small boats would be shipwrecked as the storm that caused all of this lasted for several days. Therefore it was feared that most would not resist any longer such conditions and would eventually starve. The floodwaters also entered the town of Antwerp, where it caused large-scale damage to merchants and warehouses, of which a lot would be bankrupted.

The floodwater also came into the main church of Antwerp. Here tombstones were uplifted, and graves collapsed. In the cemetery of the fortress called Vlaamse Hoofd dead bodies were lifted from their graves and floated towards the main gate of the fortress. Here the floodwaters washed a hole in the pavement of about sixty feet long, making its way to the gate in the interior, which was ruined. Then the water made it way towards the church of the fortress, making the situation very dangerous.

Also, the fortified town of Hulst was badly flooded. Along the North Sea coast of Flanders several areas were flooded too (State Archives, Bruges, Belgium). Although reports of the event from several areas hit in Zeeland were sent to the provincial capital Middelburg, mostly begging for assistance, no general relief was given. Initially all areas had to rely on themselves to make their land dry again. Soon afterwards the provincial government advised some polder boards to raise the top levels of their dikes and the commander of Hulst took many measures to strengthen the town.

The next flooding occurred on 3 March 1715, which was not as devastating as that of 1682. Many people in 1715 still remembered the flood that happened 33 years before (de Kraker, 2013). In general the same polders were hit again, but waters did not penetrate that deeply into the hinterland as they did in 1682. Also, the town of Hulst remained dry, because of the measures it had taken. In terms of flooded area it hardly surpassed $10 \%$ and in terms of casualties the 1715 flooding was hardly a serious one, except on the islands of Goeree and Overflakkee, where some polders had to be abandoned for some years.

\subsection{Strategic flooding events of the 17th and 18th centuries}

In both the Dutch part of northern Flanders and the area north of Bergen-op-Zoom a long area consisting of creeks and salt marshes was not given out for reclamation. Some already reclaimed neighbouring areas could be given back to the sea through the opening of sluices or by making breaches in seawalls.

In 1672, when the French army marched into Flanders, also threatening the Dutch part, commanders of garrisons opened sluices at several locations (Table 2, Fig. 8). One such event took place near Sas van Gent, where a large new polder (reclaimed in 1652) was given up and flooded (State Archives, Ghent, Belgium); also further to the east, polders were flooded. Some were drained as soon as hostilities were over, others flooded again in 1682 (see above).

In the course of the 18th century and after another threat from the French, an ingenious network of sluices and channels was developed in order to generate flooding within a few days (Zeeland Archives, collection Wiltschut papers). From Liefkenshoek (northwest of Antwerp) as far west as Sluice, a long area could serve as a water barrier. Water had to reach 40 to $60 \mathrm{~cm}$, which prevented guns being dragged or the use of boats, while foot soldiers could easily be stopped.

At the start, strategic flooding events mainly used sea water, but by the end of the 18th century fresh water could also be used, by simply leaving sluices closed. This last case required the building of special parts in the big sluices that were built of stone and brick.

\subsection{Strategic flooding in 1940-1944}

During the Second World War both the German occupying army and in 1944 the liberating allied forces used inundation as part of their military strategy (Table 2, Fig. 8). Flooding could be used for both defensive and offensive warfare. 


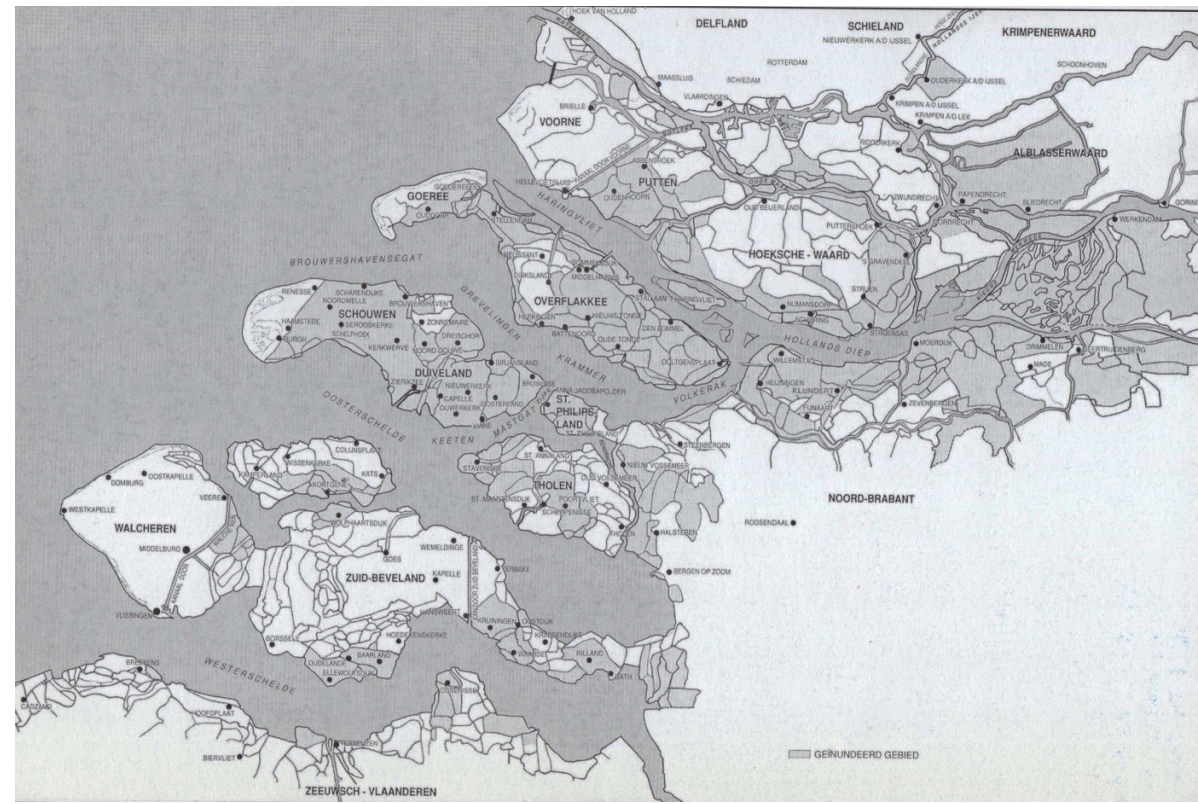

Figure 4. Reconstruction of the flooded areas (shaded) in Zeeland, parts of the provinces of South Holland and North Brabant during the storm surge of 1 February 1953.

As the allied threat of invading the continent of Europe became greater and finally the allied armies marched from France north to liberate Belgium and the Netherlands, the Germans had already begun to make plans to flood parts of Zeeland. In April, flooding near Axel started, which was a fresh water flooding (van der Ham, 1990, 277-278). Around the same time the islands of Schouwen-Duiveland, Tholen and St. Annaland were flooded too. Flooding here was undertaken by opening sluices and allowing sea water to come into the polders.

The allied forces moved quickly northwards in mid-1944. In order to gain control over the mouth of the Western Scheldt and use Antwerp for providing the troops, on 1 October General Eisenhower gave the command to chase the Nazis off the main island of Walcheren by flooding the entire island. The Walcheren landscape resembled a basin which would fill with water within a day. The allied forces bombed the seawall at four locations, through which deep and broad gaps water flooded the island (van der Ham, 1990, 439-443). As a result the Nazis surrendered Walcheren and left it within days. The impact of the flooding was huge, not only on the four locations, where much collateral damage to properties was caused, but over 150 people also perished during the blast. As the flooding occurred on 3 October 1944, much additional damage was caused during the bad weather over the following weeks.

\subsection{3 flooding event}

The most recent and by far most devastating flood event occurred on 1 February 1953. A W to NW storm blew for two whole days, pushing up the tides to extreme heights into the inlets of the rivers Meuse, Eastern and Western Scheldt on the Dutch side and the river Thames on the British side of the southern North Sea. Due to its long duration and extreme high water levels, vast areas flooded. In particular, the islands of Schouwen-Duiveland and Goeree-Overflakkee and neighbouring areas nearly completely flooded. Flooding reached as far north as Dordrecht and to the east even beyond Geertruidenberg (Fig. 4). The numerous reports and testimonies of the disaster, still revealing new facts after so many years are very similar to the description of the dramatic consequences of the 1682 flood event. However, damage can also be summarised in terms of facts and figures, such as 200000 ha land flooded, 100000 people evacuated, 1836 people dead and overall damage EUR 700 million in 1953 (Slager, 2003, p. 7).

\section{Discussion}

Looking at the selection of flood events in the SW Netherlands of the last five centuries, it is clearly demonstrated that no flooding event was alike, but generally two categories of flood events can be distinguished, the first one being the flooding events occurring during storm surges. The second category consists of flooding events during warfare or related to war. There is also a special category of flooding events which have to do with erosion in meanders of the mouths of the rivers Scheldt and Meuse. Because these are local and incidental, they have not been considered in this paper. 


\subsection{Storm surges}

Most flood events occur during storm surges usually unexpectedly, sometimes during the day time, sometimes at night, but always during the storm season (October-March) and in particular two days after New or Full Moon. The impact of the event depended on many circumstantial and additional conditions, which will briefly be discussed.

One of the conditions of large-scale flooding during a storm surge was long duration combined with strong winds. During the 1953 storm surge, wind force hardly surpassed 9 Beaufort, but the surge lasted for more than two successive high tides (Hickey, 2001). After the first high tide, which was already dangerously high, the following ebb tide also remained high, which consequently caused the second high tide to be higher than the first high tide. Also, the flooding event of 1530 is known for its extreme high level. Some contemporaries spoke of two feet or even a beer barrel's height above the top level of some dikes, which meant that water level was more than half a metre higher than top levels of dikes at the time. Because each polder or water board maintained its own standards for top level height, it is hard to generalise flood level back in 1530 . More likely big waves were pushed over the dikes during gusts of strong wind, which led water to affect the landside slope of dikes which were more brittle than the extra defended gentle slope on the seaward side. If this went on for hours, dikes could collapse from the landward side very easily; such collapses were widely observed in 1953 in the SW Netherlands again. Once such collapse started, the top level slid down (like a very local landslide), making a hole in the dike through which water could penetrate into polders making deep erosive gaps.

Flooding during a storm surge could also occur if two or more extreme weather events happened within a short time span. The 1421-1424 Elisabethan floods (Leenders, 2009), 1509-1511, and the 1530-1532 and January-February 1552 storm surges all came in pairs. Areas hit during the first storm surge were either not given enough time for repairs to be undertaken or dikes that had already been repaired properly still proved to be too weak and therefore collapsed again as the second surge hit the area. At this point there is a great amount of resemblance between communities hit by two successive years of crop failure and communities hit by two successive flooding events (Campbell, 2010). In both cases resilience is put to the highest test, usually meaning that contemporaries could not cope well with such extremes reoccurring in fast succession.

The opposite is also true. This is the case of the 1682 flooding, which seems to have come out of the blue, being the second extreme event of its kind in the area during the entire 17th century. As the first flooding occurred on Easter Monday 1606 , nobody in 1682 had any recollection of that early flood, which most likely had made water boards less vigilant, leading to neglect of extra maintenance of dikes. The 1682 flood also hit major trade centres such as Antwerp and Flush- ing, inflicting damage to stocks and other properties. For the region of Zeeuws-Vlaanderen it should be noted that the vastness of the flooded area must have partly contributed to the strategic flooding that occurred barely a decade before. Not all of the flooded area had been properly recovered, while some flooded polders were left disputed, because landowners did not want to pay for all the drainage costs themselves. The 1715 flooding demonstrates that some extra measures taken after 1682 paid off, but not everywhere (de Kraker, 2013). It should be noted that the storm surges, such as 1715, happening during day time, did not come as such a surprise as the 1682 one. Compared to other 18th century storm events and storm surges, the 1715 flood event must be considered as being the major flooding event of its century in the SW Netherlands (Baart et al., 2011; Demarée and Muir-Wood, 2009; Pfister et al., 2010).

The 1953 flooding event in the SW Netherlands, compared to the other flooding events, is special in many ways. It is not only the extremely high water level reached on 1 February which generally is considered to be its main cause. It happened at a time that most people could have still remembered the 1906 flood, which was a rather small-scale event not having caused large-scale flooding and not having caused a large human toll. There are more factors to be considered, one of them being the failure to raise top levels of dikes regularly up to a level of $6 \mathrm{~m}$, as was ordered by Rijkswaterstaat. So it was common knowledge that dikes were too low. At places where top levels had been raised this was undertaken by building concrete walls (Muralt walls) on top of the dike which were fastened into the topsoil. Because of the wave action and the sheer volume of water, these concrete walls were simply pushed over the dikes during the storm surge. The extent of the flooding was also very much caused by the slow response of officials of local water boards. As the flooding happened on Sunday morning, many people were attending church service or were still asleep. At the same time it clearly exposed the weakness of the water board organisation, consisting of about 300 water boards all having to decide which measures had to be taken to prevent that one dramatic flooding event. The large-scale material damage and the high human toll were also largely caused by the weak buildings in the flooded area not withstanding the impact of the incoming tide. So many having taken refuge on rooftops (compare 1682) still did not make it because their houses collapsed. Most had to wait and endure the cold until relief came, which during the first days consisted of fishing boats and other vessels, while only two helicopters were available.

\subsection{Strategic flooding}

Looking at the second category of flooding events, caused by the military and occurring during warfare or prior to the threat of an enemy invasion, demonstrates that especially the flooding during the Eighty Year's War stands out as a set of major events. As the rebel side asked experts of the lo- 


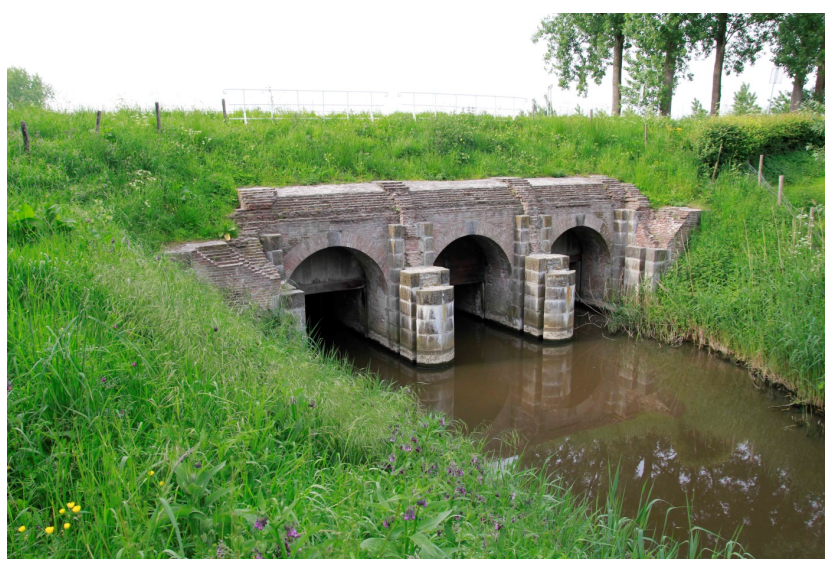

Figure 5. Land side of an inundation sluice, built in 1789 by the Estates General of the Dutch Republic at Zwartenhoek $\left(51^{\circ} 15^{\prime} \mathrm{N}\right.$ and $\left.3^{\circ} 51^{\prime} \mathrm{E}\right)$. Notice the double groove in the protruding parts in which beams could be installed. As the space in between the beams could be filled with earth, this construction was strong enough to prevent the fresh water from flowing seaward. After some weeks water in polders could reach a level of some decimetres. As soon as the threat of war disappeared, beams and earth were removed again (photo: Nellie de Kraker).

cal water boards to advise on the locations where breaches should be made, this guaranteed the largest possible extent of such a flooding. The initial intention was to have water in polder areas standing two feet high. This prevented the use of flat bottomed barges and made it impossible to drag heavy artillery through the area. As the flooding in some areas remained too limited, it was soon ordered to also make breaches in secondary dikes lying more inland, so that water could penetrate as deeply as possible into the area. As there was no backup plan for repairs after hostilities, no dikes were repaired (t'Hart, 2014, 105-107). Moreover, soon the flooded area became part of a strategic line of defence. From then onwards reclamation of flooded land could only be undertaken with a special permit from the government, who first asked the advice of the military. The long duration of the war (1568-1648) and the incorporation of the flooded areas into further warfare had profound consequences for the landscape. Large and deep new tidal channels formed, such as Saeftingher Gat, Hellegat, Braakman and Havengat in Zeeuws-Vlaanderen, clearing old medieval settlements and other structures. Floodwaters used the old ditches and canals to finally fill the areas where large-scale subsidence of surface level had taken place by cutting peat for fuel and salt making. On the other hand, a thick new clay layer was deposited at most places. At places designated as strategic inundation areas the process of depositing would go on until the end of the 18th century. Here the level of the salt marshes had already become so high that the strategy of flooding had become inefficient and therefore completely outdated.

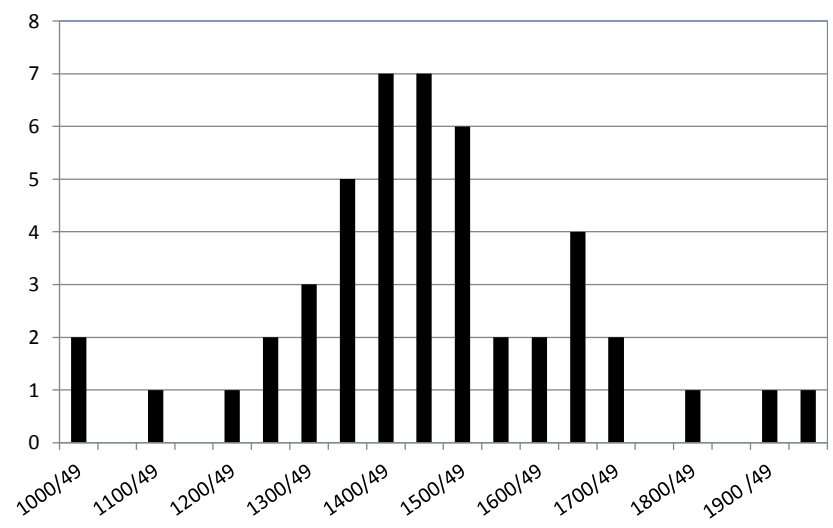

Figure 6. Number of flood events caused by storm surges in the SW Netherlands, 1000-2000, per half a century. This number does not say anything about intensity, damage or scale; most of the events barely flooded $5 \%$ of the territory, others (16 November 1530 , 12 November 1570) perhaps about one third.

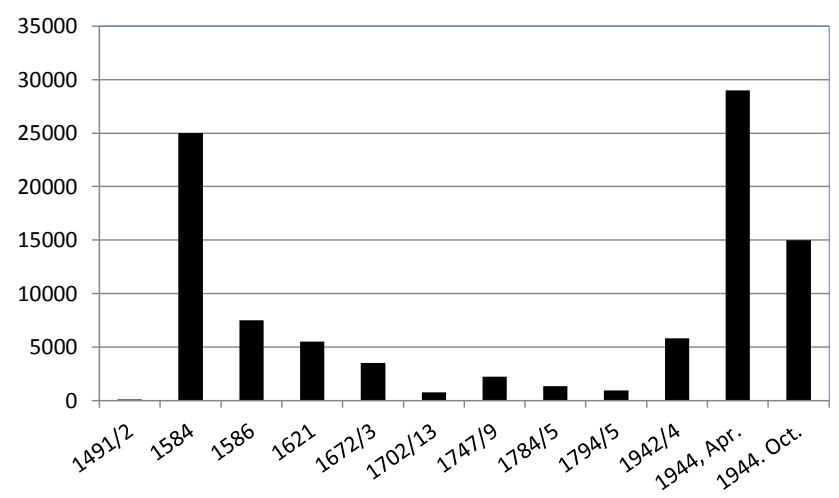

Figure 7. Flood events caused during warfare in the SW Netherlands, 1491-1944. The intensity and damage are indicated in hectares.

Another consequence of this kind of flooding on the landscape was that salt water had a devastating effect on crops during the first few years. Because strategic flooding events were undertaken in the common interest, no compensation was paid to farmers. It was not until the end of the 18th century that the view on strategic flooding began to change. Instead of using sea water, fresh water could also be used. This led to the building of special sluices, inundation sluices, that were able to store the fresh water in the polder areas (Fig. 5). However, there was only one major problem. If an enemy army attacked by surprise, there was not enough time for a fresh water inundation to reach a level of two feet in polders. This took some weeks and was almost completely dependent on rainfall. Intensively spying on the enemy could provide information far in advance and, as a result of this, flooding could already be set in motion. In 1784/1785 strategic flooding proved to be completely unnecessary because no enemy 
force came to the area. The outcome was a growing opposition against this weapon of war.

The strategic flooding events of the Second World War show two faces. The Nazi flooding of parts of ZeeuwsVlaanderen with fresh water and the islands of SchouwenDuveland, Tholen and St. Philipsland with sea water were caused far in advance of a possible allied attack. This way there was time enough for the water to rise to the level aimed at. Moreover, weak locations could be re-enforced properly. Being purely defensive, these flooding events did not stop the allied forces from marching north and only slowed them down. The allied strategic flooding of the former island of Walcheren in 1944 was undertaken within a day, allowing sea water to flood $70 \%$ of the island. It proved to be very effective. The Nazis immediately surrendered the island to the allied forces and then repairs began, but only after months were gaps closed and dikes rebuilt and re-enforced. Meanwhile, the flooding of the island was the main cause for undertaking a major land re-allotment and land consolidation in the years after. This meant that by 1953 this area in the SW Netherlands had already been changed to meet the demands of modern times, including its seawalls, from which it benefitted very much during the storm surge that year, when only a small strip in the east of the island was flooded.

\subsection{Comparison and the wider scope}

Comparing the two categories of flooding events (storm surges and warfare), it needs to be said that the human factor plays a major role in both. Strategic flooding events are caused by man, but water as a natural feature should finish the job by pushing into areas making them inaccessible. Flooding events during storm surge do have an important natural component which as such could be very devastating, but much depends on the vigilance and resilience of humans in preventing this from happening or to limit damage as much as possible. Five centuries of flooding events in the SW Netherlands have made it clear how vital the anthropogenic factor is in having an influence on the kind, extent and the duration of flooding. Since 1953 it has been the dominant factor in the prevention of further flooding events in the area and still is.

A comparison between the coastal flooding events in the SW Netherlands and flooding in more upstream river areas demonstrates both the similarities and the differences. Upstream river areas and the lower river basins not being under tidal influence tend to flood at times of extreme rainfall, peak discharge caused by sudden thaw, ice blocking or a combination of such events. None of these factors plays a role of any significance in the tidal inlets of rivers. There have only been two events of ice playing a role in coastal areas. In both cases a lengthy period of frost caused sluices to become jammed. After having been defrosted, the sluice doors could function again. The large-scale strategic flooding events in the Dutch river area between 1672 and 1795 were caused partly by piercing the river dikes in place. Especially during the French War of 1672-1678 it caused large-scale flooding in central Holland and Utrecht, which rendered areas out of agrarian use for some years. At that time this Old Dutch Water Line proved to be effective. It was to be extended further south and east in later centuries (New Dutch Water Line), with additional strategic flooding areas around the rivers Lower Rhine and IJssel. None of these ever achieved their ultimate goals.

Looking at the flooding events in the SW Netherlands, 1500-2000, and putting them in a much wider European scope of flooding events, it becomes clear that there is a much longer tradition of researching flooding events in the Netherlands. This is especially due to the fact of the vulnerability of the Dutch landscape to both coastal and river flooding. It is low lying with large parts below sea level, and three major rivers (Rhine, Meuse and Scheldt) form a kind of delta near the North Sea. Dike building along with other coastal defences and embedding of many water boards has been the response to flooding in the past, it still is in the present and will be far into the future. Regarding this long tradition and the very nature of the Dutch landscape, the use of flooding as part of a military strategy sounds logical. Flooding events outside the Netherlands have begun to receive special attention as climate has contributed to some major river flooding in various parts of Europe in the past few decades (Glaser and Strangl, 2004; Brázdil et al., 2012). In terms of causes and consequences, there are differences with flooding events in the Netherlands. The most important cause of recent flooding across Europe are extreme rainfall events, even in summer, while in Dutch coastal flooding, storm surges and gale force storms play a major role. In river areas across Europe, such as central Europe (River Danube, Kiss and Laslovszky (2013); Rohr (2013); River Rhine, Wetter et al. (2011); and River Elbe) most damage is caused in river towns, while in the Netherlands mostly rural areas were hit. Finally, the response to flooding in the Netherlands is a large-scale project which gives more room for rivers to run through densely populated areas and to store large amounts of water of which some aspects go back to the early 19th century. Across Europe such projects are just beginning to be developed. Studies on flood events across Europe therefore began to focus on flooding events of the past, unravelling patterns, how people responded to events, and what measures they took. Having studied that, the challenge is how to deal with present and future flooding in a generally highly urbanised environment, which is completely different from the landscapes of the past.

A last aspect that needs to be mentioned is the present urge to again flood areas in the SW coastal area of the Netherlands. This is not motivated anymore by strategic reasons or economic reasons. It has to do with restoring lost tidal landscapes. Within the framework of Natura 2000 tidal wetlands are made again, however without little knowledge of flood events of the past centuries. 


\section{Conclusions}

This paper set out to explore how natural flood events of the last five centuries in the SW Netherlands were. These flooding events have been classified into two groups: flooding events caused by storm surges and flooding events occurring during warfare. The multiple-century overview of the events has demonstrated that the first category has an initial natural cause, being meteorological in terms of severe gale force Beaufort 8-11 coinciding with New and Full Moon and human intervention in terms of vigilance and resilience. As no flooding events caused during storm surge are alike, the extent of the flooding and the damage caused depended a great deal on the duration, wind force, time of day or night and the weather condition at that particular date. Moreover, the human response to each flood event also differs a great deal, depending on how often such flooding events occurred during a lifetime, how fast a second flooding happened, the organisation of the local water boards, and the state and maintenance of dikes, while sometimes much depended on the individual measures people were willing to take. The second group of flooding events occurring during warfare are man made, either caused by fresh water or - as was the case before 1800 in the SW Netherlands - by sea water. The strategic flooding during the Eighty Year's War failed to facilitate the rebel offensive to free the besieged towns of Ghent, Bruges and Antwerp. The strategic flooding of later centuries failed as a defensive strategy to stop the French armies from invading the area. Although the strategic flooding during the Second World War did not prevent the Nazis from stopping the allied march, it did help the allies in liberating parts of the SW Netherlands before the winter of 1944/1945 began.

The impact of flooding events caused during storm surges and those happening during warfare is different. In terms of extent of flooding and devastation, the strategic flooding events of 1584-1586 and 1621 had the biggest impact on the landscape; so did the 1953 flooding caused during a storm surge.

Acknowledgements. I would like to thank A. Kiss, C. Rohr and $\mathrm{N}$. Macdonald for the valuable suggestion and advice given.

Edited by: A. Kiss

\section{References}

Baart, F., Bakker, M. A. J., van Dongeren, A., den Heijer, C., van Heteren, S., Smit, M. W. J., van Koningsveld, M., and Pool, A.: Using 18th century storm-surge data from the Dutch Coast to improve the confidence in flood-risk estimates, Nat. Hazards Earth Syst. Sci., 11, 2791-2801, doi:10.5194/nhess-11-27912011, 2011.

Baeteman, C.: History of research and state of the art of the Holocene depositional history of the Belgian coastal plain, in:
Landscapes or Seascapes? The history of the coastal environment in the North Sea area reconsidered, Corn Publication Series, Comparative Rural History of the North Sea Area, edited by: Thoen, E., Borger, G. J., de Kraker, A. M. J., Soens, T., Tys, D., Vervaet, L., and Weerts, H., 13 Brepols, Gent, 11-30, 2013.

Borger, G. J.: Draining-digging-dredging; the creation of a new landscape in the peat areas of the Low Countries, in: Fens and bogs in the Netherlands: vegetation, history, nutrient dynamics and conservation, edited by: Verhoeven, J. T. A., Geobotany, 18, 131-171, 1992.

Bosch, T.: Changing societies produce changing rivers, Managing the Rhine in Germany and Holland in a changing Environment, 1770-1850, in: A History of Water, Series II Volume 2: Rivers and Society: From Early Civilizations to Modern Times, edited by: Tvedt, T. and Coopey, R., I. B. Tauris, London, New York, 263-286, 2010.

Brázdil, R., Kundzewicz, Z. W., Benito, G., Demarée, G., Macdonald, N., and Roald, L. A.: Historical floods in Europe in the Past Millennium, in: Changes in Flood Risk in Europe, IAHS Special Publication 10, edited by: Kundezwicz, Z. W., IAHS Press and CRC Press/Balkema, Wallingford, 121-166, 2012.

Campbell, B. M. S.: Nature as historical protagonist: environment and society in pore-industrial England, Econ. Hist. Rev., 63, 281314, 2010.

de Kraker, A. M. J.: Landschap uit balans. De invloed van de natuur, de economie en de politiek op de ontwikkeling van het landschap in de Vier Ambachten en het Land van Saeftinghe tussen 1488 en 1609, Matrijs, Utrecht, 1997.

de Kraker, A. M. J.: Modernization of dike maintenance and coastal management in the Meuse-Schelde-Delta, 1500-1900, in: Kulturlandschaft Marsch, Natur - Geschichte - Gegenwart, Vorträge anlässlich des Symposiums, 3-5 June 2004, Oldenburg, edited by: Fansa, M., Isensee-Verlag Oldenburg, Oldenburg, 146-161, 2005.

de Kraker, A. M. J.: De centra van zoutproductie in Brabant, Vlaanderen en Zeeland tussen 1400 en 1600, in: Veen-Vis-Zout Landschappelijke dynamiek in de zuidwestelijke delta van de Lage Landen Geoarchaeological and Bioarchaeological Studies 8, edited by: de Kraker, A. M. J. and Borger, G. J., Vrije Universiteit Amsterdam, Amsterdam, 81-113, 2007.

de Kraker, A. M. J. and Bauwens, W. E. M.: Polders en Waterschappen in het Hulsterambacht. De geschiedenis van zeedijken, vooroever, binnenwater, wegen en van de bestuurlijke organisatie van de waterschappen in het voormalige Hulsterambacht tussen 1600 en 1999, Kloosterzande, 2000.

de Kraker, A. M. J., de Koning, D., and Wielinga, R.: Making salt the medieval way, in: Experimentelle Archäologie in Europa, Bilanz 2008, Heft 7, European Association for the Advancement of Archaeology by Experiment, Oldenburg, 75-90, 2008.

de Kraker, A. M. J.: Sustainable coastal management, past, present and future or how to deal with the tides, Water History, 3, 145164, 2011a.

de Kraker, A. M. J.: De rol van de cisterciënzerabdijen in het kust- en het waterbeheer in Noordoost-Vlaanderen tijdens de $15^{\text {de }}-16^{\text {de }}$ eeuw, Novi Monasterii, Jaarboek Abdijmuseum Ten Duinen 1138, 11, 75-84, $2011 \mathrm{~b}$.

de Kraker, A. M. J.: Two floods compared. Perception of and Response to the 1682 and 1715 flooding disasters in the Low Countries, in: Forces of Nature and Cultural Responses, edited by: 
Pfeifer, N. and Pfeifer, K., Springer Verlag, Dordrecht, 287-302, 2013.

Demarée, G. R. and Muir-Wood, R.: De 'Grote Storm van December 1703 ' in de Lage Landen - een stormachtige periode in de Spaanse Successieoorlog, in: Jaarboek voor Ecologische Geschiedenis 2008, Klimaat en atmosfeer in beweging, edited by: De Kraker, A. M. J. and van der Windt, H. J., Academia Press, Ghent, 33-54, 2009.

Essink, K. (Ed.): Stormvloed 1509, Geschiedenis van de Dollard, Stichting Verdronken Geschiedenis, Groningen, 2013.

Glaser, R. and Strangl, H.: Climate and floods in Central Europe since AD 10000: data, methods, results and consequences, Surv. Geophys., 25, 485-510, 2004.

Gottschalk, M. K. E.: Storm surges and river floods in the Netherlands, Van Gorcum \& Comp., N. V. Assen, 3 vols, 1971-1977.

Groenveld, S., Leeuwenberg, H. L. P., Mout, M. E. H. N., and Zappey, W. M. (Eds.): De Tachtigjarige Oorlog. Opstand en consolidatie in de Nederlanden (ca. 1560-1650), Walburg Pers, Zutphen, 2008.

Hickey, K. R.: The storm of 31 January to 1 February 1953 and its impact on Scotland, Scott. Geogr. J., 117, 283-295, 2001.

Kiss, A. and Laslovszky, J. $: 14^{\text {th }}-16^{\text {th }}$ century Danube floods and long-term water-level changes in archaeological and sedimentary evidence in the western and central Carpathian Basin: An overview with documentary comparison, J. Environ. Geogr., 6, 1-11, 2013.

Kluiving, S. J., Brand, N., and Borger, G. J. (Eds.): De WestBrabantse Delta: een Verdronken Landschap Vormgeven, Geoarchaeological and Bioarchaeological Studies 7, Institute for Geoarchaeology and Bioarchaeology, Amsterdam, 2006.

Kool-Blokland, J. L.: De Rand van't Land, Waterschapsgeschiedenis van Schouwen Duiveland, Werken uitgegeven door het Koninklijk Zeeuwsch Genootschap der Wetenschappen, no. 13, Middelburg, 2003

Leenders, K: 'Die inundacie ende inbreck van onsen Grooten Waert' De verdrinking van de Grote Waard, in: Nijet dan water ende wolcken, De onderzoekscommissie naar de aanwassen in de Verdronken Waard (1521-1523), edited by: Wikaart, V., Stichting Zuidelijk Historisch Contract, Tilburg, 65-74, 2009.

Municipal Library: (Kortrijk, Belgium), ms. 175, p. 460.

National Archives of Belgium (Brussels) Auditory of Flanders, no. 27866, fol. 55verso. State Archives at Ghent (Belgium), Council of Flanders, no. 3768 enquiry of 7 July 1513. Town Archives of Hulst, town account 1511-1512.

Pfister, C., Garnier, E., Alcoforado, M.-J., Wheeler, D., Luterbacher, J., Nunes, M. F., and Taborda, J. P.: The meteorological framework and the cultural memory of three severe winter-storms in early eighteenth-century Europe, Climatic Change, 101, 281310,2010

Rohr, C.: Floods of the Upper Danube River and its tributaries and their impact on urban economies (c. 1350-1600): The examples of the towns of Krems/Stein and Wels (Austria), Environ. Hist., 19, 133-148, 2013.

Royal Library 'Albert I', (Brussels, Belgium), ms. 19175, fol. 188189.

t'Hart, M.: The Dutch wars of independence. Warfare and commerce in the Netherlands, Routledge, London, New York, 1570$1680,2014$.
Town Archive, Bruges, Belgium, town account, 1509-1510, fol. 85ro.

Slager, K.: De Ramp. Een reconstructie van de watersnood van 1953, Uitgeverij Atlas - Amsterdam - Antwerp, 2003.

State Archives, Bruges, Belgium, Vrije van Brugge, no. 106.

State Archives, Ghent, Belgium, Boudelo abbey, no. 2757, resolution of 19 October 1672 to breach dikes near Sas van Ghent.

van Dam, P. J. E. M.: Sinking Peat Bogs. Environmental Change in Holland, 1350-1550, Environ. Hist., 6, 32-46, 2001.

van Dam, P. J. E. M.: Denken over natuurrampen, overstromingen en de amfibische cultuur, Tijdschrift voor Waterstaatsgeschiedenis, 1 and 2 June/December, Uitgeverij Verloren, Hilversum, 110, 2012.

van der Ham, G.: Zeeland, 1940-1945, Waanders, Zwolle, 1990.

van de Spek, A. J. F.: Tidal asymmetry and long-term evolution of Holocene tidal basins in The Netherlands: simulation of palaeotides in the Schelde estuary, Mar. Geol., 141, 71-90, 1997.

van de Ven, P. G. (Ed.): Man-made lowlands. History of water management and land reclamation in the Netherlands, Uitgeverij Matrijs, Utrecht, 1993.

van Tielhof, M. and van Dam, P. J. E. M.: Waterstaat in stedenland, Het hoogheemraadschap van Rijnland voor 1857, Uitgeverij Matrijs, Utrecht, 2006.

Verhulst, A.: Landschap en landbouw in middeleeuws Vlaanderen, Brussels Gemeentekrediet, Gemeente Krediet, Brussels, 1995.

Weerts, H.: Holocene sea-level change, sedimentation, coastal change and palaeogeography in the southern North Sea lowland. A 2012 geological literature overview, in: Landscapes or Seascapes? The history of the coastal environment in the North Sea area reconsidered, Corn Publication Series, Comparative Rural History of the North Sea Area, edited by: Thoen, E., Borger, G. J., de Kraker, A. M. J., Soens, T., Tys, D., Vervaet, L., and Weerts, H., 13 Brepols, Gent, 145-176, 2013.

Wetter, O., Pfister, C., Weingartner, R., Luterbachter, J., Reist, T., and Trösch, J.: The largest floods in the High Rhine basin since 1268 assessed from documentary and instrumental evidence, Hydrolog. Sci. J., 56, 733-758, 2011.

Zeeland Archives, Estates of Zeeland, no. 1623, fol. 200recto, instruction of 5 May 1584 to breach the dikes at Campen; fol. 206, minute of 16 May 1584 to deputy at The Hague; fol. 214verso, minute of 28 May 1484 to the besieged town of Antwerp; no. 1198, letter of 6 May 1584 from the besieged town of Antwerp; letter of 10 May 1584 from Cornelis Claeys (commissioned to undertake the breach), Concerning the breach at Nieuw-Othene: Zeeland Archives (Middelburg), Estates of Zeeland, no. 1623, fol. 234verso, minute of 18 July 1584 holding instruction for captains Caulier and Drooge to make the breach; fol. 240verso-245verso, minute of 28 July 1584 to captain Caulier with congratulations on the occasion of a successful breach made, Concerning the breaches made at Aardenburg-Sluis in 1584; Zeeland Archives, Estates of Zeeland, no. 469, resolutions of 9, 13, 21, 24 and 25 March 1584; no. 1623 fol. 165recto169recto, minutes of 13, and 22 March 1585 to the besieged town of Bruges. 